\title{
The Declining Information Content of Dividend Announcements and the Effects of Institutional Holdings
}

\author{
Yakov Amihud* and Kefei $\mathrm{Li}^{+}$
}

Forthcoming, Journal of Financial and Quantitative Analysis

May 2005

*Ira L. Rennert Professor of Finance, Stern School of Business, New York University. ${ }^{+}$Morgan Stanley.

We thank Viral Acharya, Eli Berkovitch, Deborah Goldstein, Bill Greene, Ronen Israel, Larry White and participants in the workshop of Tel Aviv University, the Hebrew University, University of Binghamton and MIT for helpful comments. We thank an anonymous referee for suggestions that helped improve the paper. 


\title{
The Declining Information Content of Dividend Announcements and the Effects of Institutional Holdings
}

\begin{abstract}
We propose an explanation for the "disappearing dividend" phenomenon: a decline in the information content of dividend announcements, which reduces the propensity of firms to use dividends as a costly signal. A reason for a decline in the information content of dividends is the rise in holdings by institutional investors that are more sophisticated and informed. We indeed find a decline in $C A R$ at dividend change announcements since the mid 1970s. Across firms, CAR is a decreasing function of institutional holdings.

Institutional investors exploit their superior information and buy before dividend

increases. And, dividends are less likely to rise in firms with high institutional holdings.
\end{abstract}




\section{Introduction}

Fama and French (2001) present the phenomenon of the "disappearing dividend:" since 1978, the propensity of public companies to pay dividends has declined. They show that companies are continuously less likely to pay dividends, after controlling for their changing characteristics. Grullon and Michaely (2002) document a decline in both the dividend payout ratio and in the dividend yield, and Allen and Michaely (2003) find that the number of firms that announce dividend increases has declined since 1978.

We propose an explanation for the disappearing dividend: a decline in the information content of dividend announcements. Dividends are a means to signal information and indeed, stock prices react positively to dividend change announcements (Aharony and Swary, 1980 and a survey in Allen and Michaely, 2003). Signaling by dividends entails costs: shortfall in resources that requires raising capital, which is costly (Bhattacharya, 1979, Ofer and Thakor, 1987), higher tax (John and Williams, 1985) or suboptimal investment (Miller and Rock, 1985). These costs are necessary to generate a signaling equilibrium. The positive reaction of stock prices to announcements of dividend increases, in spite of their cost, reflects the positive information about the firm value that these announcements convey (see Handjinicolaou and Kalay, 1984). Indeed, Ofer and Siegel (1987) show that following announcements of dividend changes, analysts update accordingly their expectations of the firm's future earnings.

Thus, if dividend increase announcements have become less informative, firms may want to save the dividend-related costs by reducing the use of dividends as means to convey information. Hence the phenomenon of disappearing dividends.

Testing our proposition, we find the following: 
a. There is a decline in the cumulative abnormal return, $C A R$, at the announcement of dividend increases since the late 1970s. This pattern is consistent with the documented decline since the late 1970 s in the propensity of firms to pay dividends or increase dividends. Also, the negative CAR at dividend decrease announcements rose towards zero.

b. The dividend response coefficient - the sensitivity of $C A R$ to the magnitude of dividend changes - declines since about 1980 .

Given our evidence that the information conveyed by dividend news has been declining and given that dividend signaling is costly, there has been a decline in the use of dividends as means to convey information. This explains the "disappearing dividend" phenomenon.

Next, we propose an explanation for the declining information content of dividends: the increased stockholdings by institutional investors, which are considered more sophisticated and informed than retail investors. (We review some evidence on that in Section III.) If institutional investors trade on their information about the firm's value, then by the time that a dividend increase is announced, part of this information is already incorporated in its stock price and there is less additional information conveyed by the dividend increase announcement. It follows that the role of dividends as a means of conveying information about the firm's value is smaller in firms with high institutional holdings. Consequently, a decline over time in the information content of dividend is partly due to the well-known increase in institutional stockholdings over time.

Other factors may affect a decline over time in the information content of dividend news, such as the increased availability of public information about public 
companies - investor newsletters, analyst reports, media coverage (specialized television and radio channels) and the recent increased use of the Internet. Our explanation for the declining dividends does not exclude other explanations, ${ }^{1}$ such as changes in taxes and investor sentiment. These, however, are market-wide phenomena that affect the time series of the price reaction to dividend news and cannot be tested across stocks. Since trended series can produce spurious correlations, we focus our tests on cross-sectional analysis.

We test across stocks our hypotheses on the effects of institutional holdings, denoted INST, and find the following:

a. $C A R$ at dividend increase announcements is significantly lower in firms with higher INST.

b. The dividend response coefficient is declining significantly as a function of INST.

c. Institutional investors increase their holdings in stocks that subsequently raise dividends.

d. The propensity of firms to increase dividends is a declining function of INST. These findings support in a number of ways our hypothesis that greater institutional holdings lead to lower information content of dividend news, which in turn makes signaling by dividends less valuable. We suggest that this has contributed to the documented disappearance of dividends.

Surely, signaling is not the only reason why firms pay dividends. Our study suggests that the signaling motive for paying dividends has declined over time, as evident

\footnotetext{
1 DeAngelo, DeAngelo and Skinner (2004) demonstrate the phenomenon of concentration of dividends: less companies - the larger ones - pay dividends, but their real dividends are rising.
} 
from a decline in the information content of dividend news, and that this has been particularly strong in firms that have high institutional holdings. (But dividends are also paid for other reasons.)

An alternative explanation for our results is based on the institutional investors' role as monitors of the firm's management, which reduces agency costs (Gillan and Starks, 2001). Dividends, which reduce free cash flows, subject the firm to screening and monitoring by the market when it raises capital (Easterbrook, 1984). If monitoring by institutional investors substitutes for the monitoring role of dividends, dividend increases are less valuable in firms with large institutional holdings. This explains both a decline over time in the stock price reaction to dividend increases, and a decline in dividends altogether.

The paper proceeds as follows. In Section II, we present the evidence on a decline in the information content of dividend announcements over time. In Section III, we show the effect of institutional holdings on the price impact of dividends and on the firms' propensity to raise dividends to the level of institutional ownership and document the institutional investors' trading patterns around dividend announcements. We summarize the results in Section IV and offer some concluding remarks.

\section{Stock price reaction over time to dividend announcements}

The signaling theory of dividends suggests that the effect of dividend change announcements on stock prices reflects information about future firm value. In this section, we estimate the stock price reaction to dividend change announcements and present evidence that it has been declining over time. 


\section{A. Data}

We consider all regular quarterly dividend announcements on ordinary common stocks in the CRSP daily file for NYSE\AMEX stocks, starting in July 1962. We exclude dividends defined as special, year-end, interim or non-recurring and dividends paid at other frequencies or in foreign currency, dividend initiations and resumptions, and dividend changes that result from mergers or acquisitions, stock splits, and other events that adjust prices. $^{2}$ We require that there is no announcement of other distributions in a 30-day window (days -15 to 15 day surrounding the announcement). We also exclude firms in the financial service sector (SIC code from 6000 - 6999) or in the public service (utility) sector (4900-4999), closed-end funds, REITs, stock certificates and ADRs. These criteria result in 16,189 events of dividend changes: 14,911 dividend increases and 1,278 dividend decreases.

B. Stock price reaction to dividend changes: pattern over time

We first examine the pattern over time of $C A R$, the two-day cumulative abnormal return over days 0 and +1 (day 0 is the dividend announcement day), calculated as the difference between the stock return and the size-based portfolio to which the stock belongs. ${ }^{3}$ The annual average, $C A R_{y}$, is depicted in Figure 1 over the years 1962-2000.

\section{INSERT FIGURE 1}

\footnotetext{
${ }^{2}$ Also excluded are dividend changes smaller than $0.5 \%$ which may reflect rounding of changes.

${ }^{3}$ We replicate the analysis using abnormal returns relative to CRSP beta-based portfolio. The results are qualitatively similar.
} 
Our novel result here is that over time, the (absolute) stock price reaction to dividend change news (both increase and decrease), $C A R$, declines towards zero. A decline actually begins in the mid-1970s after having peaked then. This pattern of $C A R_{y}$ is similar to the pattern of the propensity to pay dividends over time, documented in a number of studies. In Fama and French (2001, Figure 5), the percent of firms paying dividends in the NYSE, AMEX and Nasdaq rises between 1970 and 1978 and declines thereafter. Allen and Michaely (2003) show a similar pattern over time for the number of companies that announce dividend increases, with a decline being the greatest during the 1980s. And Baker and Wurgler (2004) show a turning point in firms' propensity to pay dividends after 1978, approximately where we find that $C A R_{y}$ starts declining (Figure 1). The similarity between the patterns of the propensity to pay dividend and our documented pattern of $C A R_{y}$ suggests that dividend decisions made by firms are positively related over time to the (absolute) stock price reaction to dividend changes. Firms' propensity to pay dividends, which are costly, declines if dividends increase announcements have smaller effect on stock prices.

Testing the time trend of $C A R_{y}$, we regress $C A R_{y}$ on $y(y=1962,1963, \ldots, 2000)$. The following are the results: ${ }^{4}$

Dividend increases:

$$
\begin{array}{ll}
C A R_{y}= & 0.43-0.0002 \cdot y \\
(t=) & (5.03)(4.97)
\end{array} \quad R^{2}=0.357
$$

\footnotetext{
${ }^{4}$ The two models are estimated together by the SUR method. The standard errors are corrected for hetersokedasticity and autocorrelation, using the Newey-West (1987) method with MA=1.
} 
Dividend decreases:

$$
\begin{array}{lll}
C A R_{y} & = & -2.63+0.0013 \cdot y \\
(t=) & (7.26)(7.14)
\end{array} \quad R^{2}=0.502
$$

The results show a significant decline over the years in the (absolute) stock price reaction to dividend change announcements. Closer examination of Figure 1 suggests that there has been a regime shift in the mid 1970s for both dividend increases and dividend decreases. Whereas until then the CAR is largely flat, even increasing the early 1970s, it largely declines since then. Fitting models (1.1) and (1.2) to the data after 1975 shows a much better fit, but we do not present these results since they reflect data snooping.

\section{The dividend response coefficient over time}

The information content of the magnitude of the change in dividend yield, $D D I V Y_{j}$, is measured by the dividend response coefficient, $\alpha_{l}$, which Bernheim and Wanz (1995) call "the bang for the buck." We estimate the following model:

$$
C A R_{j}=\alpha_{0}+\alpha_{1} D D I V Y_{j}+\alpha_{2} \operatorname{SIZEN}_{j}+\alpha_{3} L T Y L D_{j}+e_{j} .
$$

If $D D I V Y_{j}$ is informative, then $\alpha_{1}>0 . D D I V Y_{j}$ equals 4.[DIVAMT of current quarter$D I V A M T$ of previous quarter $] / P$, where DIVAMT is the dollar quarterly dividend per share (adjusted for stock dividends and splits) and $P$ is the price at the end of the month that precedes the month when the dividend is announced. ${ }^{5}$

The other variables in the regression are included as controls. SIZEN is the firm's stock value (in logarithm) at the last month prior to the dividend announcement month,

\footnotetext{
${ }^{5}$ We eliminate 6 cases where $|D D I V Y|>0.20$ (for example, an increase in dividend yield from $1 \%$ to $21 \%$ ).
} 
normalized by the S\&P 500 index (base: July 1962). ${ }^{6} \operatorname{SIZEN}_{j}$ should have negative coefficient for a number of reasons. First, large firms usually receive more attention by analysts and investors, which reduces the incremental information about the firm provided by the dividend change (Christensen and Prabhala (1995)). Firm's size is also positively correlated with the firm's age, which means that investors have more information about the firm. Also, firm's size and stock liquidity are positively correlated. If firms pay dividends to allow investors satisfy their liquidity needs without incurring transactions costs (Benarjee, Gatchev and Spindt (2003)), dividend increases are more welcome by investors in illiquid stocks, implying again a negative relationship between CAR and SIZEN. LTYLD is the long-term dividend yield, the sum of DIVAMT paid over a 12-month period ending in the month prior to the dividend announcement month, divided by the average end-of-month price during the 3-month period preceding the 12 month period. This ratio is then deflated by $(1+$ return on the $\mathrm{S} \& \mathrm{P} 500$ index $)$ for the same 12-month period to adjust for market-wide stock price movements (see Christensen and Prabhala, 1995). $L T Y L D_{j}$ captures the effects of factors that affect the level of the firm's dividend yield (discussed in detail below). The coefficient of $L T Y L D_{j}$ should be positive because dividend changes are more informative in high dividend-paying firms which have lower growth prospects, and because the surprise of dividend increase in such firms is greater. We index by $j$ the dividend change event; the variables are measured before the event and are hence known to investors by the time of the announcement. ${ }^{7}$

\footnotetext{
${ }^{6}$ Since SIZE changes (generally increases) over time, its coefficients in the cross-section regressions will vary over time. The normalization adjusts for that.

${ }^{7}$ We also estimate model (3) replacing $D D I V Y_{j}$ by the dividend surprise obtained from a Probit model of dividend changes as a function of some explanatory variable, as proposed by Christensen and Prabhala
} 


\section{INSERT FIGURE 2}

Model (3) is estimated cross-sectionally for each year ${ }^{8} y$ to obtain the dividend response coefficient $\alpha_{l y}$. The model is estimated only for dividend increases, since in some years there are too few dividend decrease announcements. The annual estimated coefficients are plotted in Figure 2, together with their five-year moving average. Figure 2 shows a decline in the five-year moving average of $\alpha_{l y}$ since the early 1980 s, consistent with the pattern of disappearing dividends depicted by Fama and French (2001).

We formally test the trend of $\alpha_{l y}$ by regressing it on $y$ (see Table 1). The coefficient is negative and significant, that is, the dividend response coefficient generally declines over time. For dividend decrease announcements, we estimate the dividend response coefficient in a pooled time-series and cross-section model for the entire period. The results are qualitatively similar: the dividend response coefficient declines over time.

Next, we use the estimated coefficients $\alpha_{l y}$ to examine the effects of some explanations for the declining information content of dividends. We estimating the model

$$
\alpha_{l y}=a_{0}+a_{1} X_{y}
$$

The variable $X_{y}$ is one of the following:

(a) $T A X_{y}=$ [weighted tax rate on dividend - weighted tax rate on capital gains]. The data source is the NBER Taxsim web site (calculated by Daniel Feenberg; data are missing for 1963 and 1965, which are excluded). The decline in TAX since the 1960s may explain the decline in $\alpha_{l y}$, since this tax differential makes dividend signaling effective (see

(1995) and Prabhala (1997). The results are qualitatively similar to those reported for $D D I V Y_{j}$ : the coefficient $\alpha_{l}$, which measures the effect of dividend surprise on $C A R$, declines over time.

${ }^{8}$ Year 1962 is deleted because of too few dividend increase observations. CRSP daily files begin in July. 
Bernheim and Wantz, 1995). ${ }^{9}$ However, Baker and Wurgler (2004) argue that the decline in $T A X_{y}$ should have increased the propensity of firms to pay dividends whereas in reality dividends declined.

(b) $I L L I Q_{y}$ measures illiquidity (in logarithms), the average over stocks and over the days of the year of stocks' daily ratio of absolute return to dollar volume. ${ }^{10} I L L I Q_{y}$ is known to decline over time (Amihud, 2002). Benarjee, Gatchev and Spindt (2003) show that improved market liquidity reduces the propensity of firms to pay dividends since the cash flow provided by dividends help investors avoid incurring illiquidity costs. Therefore, the desirability of dividends is an increasing function of illiquidity. (c) $D N D S_{y}$ is the valuation spread between dividend- and non-dividend-paying firms, which proxies for investors' demand for dividends. Baker and Wurgler (2004) propose that dividend payment by firms cater to investors' demand for dividends, hence it should increase when $D N D S_{y}$ rises.

(d) $R O A_{y}$ is the average ratio of EBITDA to total assets for all dividend-paying firms in the year. Dividend increases are more likely if $R O A$ is higher.

(e) $R E P_{y}$, stock repurchase, the dollar amount of equity purchases divided by the beginning-of-year market value of equity, averaged over all dividend-paying firms in the year (see Grinstein and Michaely (2004); this series begins in 1971). The effect of $R E P_{y}$ may be negative if it provides information about the firm that substitutes that of

\footnotetext{
${ }^{9}$ However, Amihud and Murgia (1997) find that higher tax on dividends is not necessary to make dividend news affect stock prices.

${ }^{10}$ See Amihud (2002). Hasbrouck (2004) shows that this measure is highly correlated with the price impact cost (Kyle's $\lambda)$ estimated from transaction-by-transaction microstructure data. The measure is used in an asset pricing model by Acharya and Pedersen (2004).
} 
dividends, or it may be positive if repurchases are substitutes for dividend increases and then, when dividend is increases, it is more of a surprise.

(f) $A G E_{y}$ is the average age (in log years) of all dividend paying firms obtained from the CRSP database. Grullon, Michaely and Swaminathan's (2002) "maturity hypothesis" suggests that firms' age is an important determinant of dividend policy. Since the average age of firms might have declined over time, it might explain the decline in dividends.

(g) $I N S T_{y}$ is institutional ownership of stocks (source: Federal Reserve Bank). By our hypothesis, which we test cross-sectionally in Section III, higher institutional ownership leads to a decline in the stock price reaction to dividend news.

(h) $y$ is the year, which enables to tests the trend in $\alpha_{1 y}$.

\section{INSERT TABLE 1}

The estimation results of model (4) are mostly consistent with expectations in terms of the signs of the coefficients although they are not all statistically significant. The coefficients of TAX, ILLIQ, DNDS and ROA are positive while the coefficients of $R E P, A G E$, INST and $y$ are negative. When all variables are included in the equation, none is significant. The $R^{2}$ is $47 \%$ and the F-test indicates that jointly, these variables contribute significantly to the explanation of $\alpha_{1 y}$. This is because of the problem of colinearity, since most of these variables are trending over time. For example, $\operatorname{Corr}\left(I N S T_{y}, y\right)=0.88, \operatorname{Corr}\left(\operatorname{REP}_{y}, y\right)=0.85$ and $\operatorname{Corr}\left(I N S T_{y}, A G E_{y}\right)=0.83$. Because any trending variable, such as $y$, is correlated with $\alpha_{1 y}$, we proceed to do cross-sectional analysis. Then, market-wide trending variables that are common to all firms, such as $T A X, D N D S$ and $y$, do not play a role. 
In summary, our evidence shows that the extent of new information revealed by dividend announcements has been declining over time. In the next section, we test our proposed explanation across stocks.

\section{Institutional investors and price reaction to dividend announcements}

We propose that the declining stock price reaction to dividend news is due to the increase over time in the stockholdings of institutional investors, which are more informed than retail investors. Institutional investors are more informed because they have the incentive and the ability to expend more resources on gathering and processing information about companies. Large holdings of stocks produce larger benefits from a given amount of information and thus provide incentives to obtain information.

Institutional investors also enjoy economies of scale and professional expertise, which lower their marginal cost in acquiring and processing information, and they have greater financial resources which can be employed to acquire information.

There is evidence that institutional investors' trades reflect more information relative to all trades in the market (Chakravarty, 2001) and stocks with high institutional holdings have greater information-based trading (Dennis and Weston, 2001). Jiambalvo, Rajgopal and Venkatachalam (2002) find that stock prices of firms with higher institutional holdings better reflect information about future earnings. This is consistent with the results for such firms of Alangar, Bathala and Rao (1999) on lower volatility around dividend announcements and of Bartov, Radhakrishnan and Krinski (2000) on

less information in their earnings announcements. Healy, Hutton and Palepu (1999) find 
that firms that expand their disclosure attract institutional investments, ${ }^{11}$ which suggests that more information is available about firms with large institutional holdings. Chen, Jagedeesh and Wermer (2000) find that stocks purchased by mutual funds outperform stocks that they sell, and Barber, Lee, Liu and Odean (2004) find that institutional investors gain from trade while individual investors lose, suggesting that institutional investors are more informed.

Since the more-informed institutional investors use their information in trading stocks, then by the time a dividend change is announced, part of the information that it conveys about the firm's value is already incorporated in the stock price. Thus the price reaction to this news is smaller in firms with high institutional holdings. This leads to our proposition that the well-known increase over time in institutional holdings can explain in part our evidence on the decline over time in the stock price reaction to dividend news, and consequently the evidence of Fama and French (2001) on the disappearing dividends. However, the congruence of the two phenomena over time - a rise in institutional holdings and a decline in stock price reaction to dividends - does not establish a causal relationship. We therefore examine this relationship by a crosssectional analysis, testing the following hypotheses:

Hypothesis 1: The greater the institutional ownership, the smaller the reaction of stock prices to dividend news, where stock price reaction is measured by abnormal returns and by the dividend response coefficient.

\footnotetext{
${ }^{11}$ Chidambaran and John (2001) show that large shareholders induce having managerial compensation contracts that provide incentives for greater voluntary disclosure of information.
} 
Hypothesis 2: Institutional investors increase their holdings in companies which subsequently announce increase in dividend. Therefore, by the time the dividend increases are announced, stock prices reflect the information that the institutional investors have had, and therefore the stock price reaction to the dividend news is smaller. Hypothesis 3: Firms with greater institutional holdings are less likely to raise dividends. This is because companies see then a lesser need to convey information by costly signaling through dividends.

\section{A. Data and variable definitions}

The data on institutional holdings of stocks are based on the quarterly reports in Form $13 \mathrm{~F}$ to the SEC. ${ }^{12}$ All common stock positions greater than 10,000 shares or $\$ 300,000$ must be disclosed. Our data source is CDA/Spectrum (as provided by Thomson Financial), based on the Disclosure Database. ${ }^{13}$ Institutional investors include banks, insurance companies, investment companies (mutual funds), investment advisors, ${ }^{14}$ pension funds and university endowment funds. Our data are from the second quarter of 1980 through the third quarter of 1998, except quarters 4Q1993, 1Q1994 and 2Q1994, for which data are missing, a total of 71 quarters.

\footnotetext{
${ }^{12}$ A 1978 amendment to the Securities and Exchange Act of 1934 requires all institutions with more than \$100 million of securities under discretionary management to report their holdings to the SEC.

${ }^{13}$ In a comparative study of the reliability of ownership data from several databases, Anderson and Lee (1996) conclude that the ownership data on Disclosure Database ranks above its peers.

${ }^{14}$ Includes investment managers (usually in brokerage firms) holding less than $50 \%$ of their assets in mutual funds. See Gompers and Metrick (2001) for details.
} 
To be included in the sample, a dividend change announcement must satisfy the conditions specified in section II.A and the stock must have valid institutional holding data. These criteria result in a sample of 4,910 dividend increase announcements and 448 dividend decreases. We henceforth analyze dividend increases because the sample of dividend decreases is too small in some periods for the tests that we conduct.

\section{INSERT TABLE 2}

Institutional holdings, $I N S T_{j}$, is the proportion of the firm's outstanding shares owned by institutional investors at the end of the quarter before the quarter when the dividend announcement $j$ is made. Table 2 presents the means and medians of $I N S T_{j}$ over 1980-1998. There is a clear trend of increase over time. The mean $I N S T_{j}$ almost doubles from 0.2901 in 1980 to 0.5351 in 1998 , with a similar rise in the median. $I N S T_{j}$ is larger for stocks with greater market capitalization: $\operatorname{Corr}\left(I N S T_{j}, S I Z E N_{j}\right)=0.44$ (this is the average over all quarters of the correlation in each quarter). The positive correlation suggests that institutions prefer investing in large-size stocks that are more liquid and thus enable trading of large quantities of shares with little price impact. And, larger holdings are more attractive to institutions due to economies of scale in the production of information. In the estimation models that follow, we control for firm size.

B. The effect of institutional holding on price reaction to dividend announcements

Our Hypothesis 1 is that larger institutional holdings reduce the positive response of stock prices to dividend increase announcements. This is demonstrated in the pattern of $C A R$ in Figure 3. In each quarter, we allocate the stocks with dividend increase announcements into three equal portfolios by their institutional holdings - low, medium 
and high INST - and then calculate the average CAR over days -11 to +1 for each portfolio. Figure 3 shows that the $C A R$ around dividend increase announcements is highest for stocks with low institutional holdings and lowest for stocks with high institutional holdings. The ratio of the highest to the lowest CAR is about 4 to 1 .

\section{INSERT FIGURE 3}

Next, we formally test the effect of INST on CAR, controlling for other stock characteristics, employing two estimation methods: pooled regression and the FamaMacbeth method by which we estimated the model across stocks for each year $y, y=$ $1980, \ldots 1998$, and then average the 19 annual coefficients across years. We present the weighted average of the 19 coefficients, the weights being the squared coefficient standard errors obtained from the annual cross-sectional regression. This is because the coefficient variances may differ across years due to variations in the annual number of observations (they vary between 130 and 373) and differences in the return variance.

The pooled time-series and cross-section regression model is

$$
\begin{aligned}
& C A R_{j}=a_{0}+a_{1} D D I V Y_{j}+a_{2} I N S T_{j}+a_{3} S P 500_{j}+a_{4} L T Y L D_{j}+a_{5} S_{Z I Z E N}+a_{6} A G E_{j} \\
& +a_{7} L T V O L_{j}+a_{8} I L L I Q_{j}+a_{9} R O A_{j}+a_{10} R E P_{j}+\sum_{m=1}^{56} a_{11 m} I N D_{m j}+\sum_{n=1}^{70} a_{12 n} Q T R_{n j}+e_{j}
\end{aligned}
$$

The Fama-Macbeth regressions for each year $y$ are

$$
C A R_{j y}=a_{0 y}+a_{1 y} D D I V Y_{j y}+a_{2 y} I N S T_{j y}+a_{3 y} S P 500_{j y}+a_{4 y} L T Y L D_{j y}+a_{5 y} S I Z E N_{j y}
$$

$$
+a_{6 y} A G E_{j y}+a_{7 y} L T V O L_{j y}+a_{8 y} I L L I Q_{j y}+a_{9 y} R O A_{j y}+a_{10 y} R E P_{j y}+\sum_{m=1}^{12} a_{11 m y} I N D_{m j y}+e_{j y} .
$$

$I N S T_{j}$ is the proportion of institutional holdings at the end of the quarter before the dividend increase announcement is made, and $S P 500_{j}$ is a dummy variable that equals 1 if the stock is included in the S\&P 500 index and 0 otherwise. 
By Hypothesis $1, a_{2}<0$, i.e., larger institutional holdings attenuate the generally positive $C A R$ which correspond to dividend increase announcements. Ideally, we would include in $I N S T_{j}$ only active institutional investments where information is gathered and generated, and exclude the passive ones, such as index investments. Since this is infeasible, we include in the model the dummy variable $S P 500_{j},{ }^{15}$ and expect to obtain $a_{3}>0$ : institutional holdings in S\&P500 stocks is partially passive and thus should have a less-negative effect on $C A R$.

Model (5) includes a number of control variables. Long-term dividend yields, $L T Y L D_{j}$ (the dividend yield over the 12 months before the dividend announcement), largely summarizes factors that affect the firm's dividend policy. As discussed earlier, we expect $a_{4}>0$. SIZEN $N_{j}$ is the firm's size (deflated by the S\&P 500 index, base is 1962), in logarithm. We expect $a_{5}<0$ for a number of reasons. First, large firms receive more attention by analysts and investors and therefore the dividend news is less of a surprise. Also, since $S I Z E N_{j}$ and $I N S T_{j}$ are positively correlated, inclusion of $S I Z E N_{j}$ prevents confounding of the effect of size with that of institutional holdings. SIZEN $N_{j}$ is also correlated with the firm's maturity, which positively affects dividend yield (Grullon et al. (2002)). Maturity is directly measured by $A G E_{j}$, the number of months the stock exists on CRSP, in logarithm. Since mature firms are likely to pay higher dividends, a dividend increase should be regarded as less of a surprise, implying $a_{5}<0$ and $a_{6}<0$. Finally, $S I Z E N_{j}$ is positively correlated with stock liquidity, which affects dividend policy

\footnotetext{
${ }^{15}$ We also examine an alternative specification of model (5) where the $S P 500_{j}$ is replaced by $I N S T_{j}: S P 500_{j}$. The coefficient of this variable should be positive, i.e., in a stock that is included in the S\&P 500 index, the effect of $I N S T_{j}$ on $C A R_{j}$ should be less negative. These are indeed the results that we obtain.
} 
since dividends provide liquidity for investors with liquidity needs (Banerjee, Gatchev and Spindt (2003)). Thus, dividends are more desirable in less liquid stocks, implying $a_{5}<0$. The effect of illiquidity is also tested by $I L L I Q_{j}$, the daily ratio of absolute return to total dollar volume averaged over the pre-announcement period (days -252 to -2 ). If dividends are more valuable in illiquid firms, we expect $a_{8}>0$. The model also includes $L T V O L_{j}$, long term volatility, the standard deviation of monthly stock returns in the 24 months before the month of the dividend increase announcement. If dividend news is more informative in firms with larger information asymmetry, we expect $a_{7}>0$. Finally, we include in the model $R O A_{j}$, the return on assets (EBITDA/total assets) which affects the firm's propensity to pay dividend, and $R E P_{j}$, stock repurchase (equity repurchase/market capitalization at the end of the fiscal year), both for the year before the dividend increase announcement. High $R O A_{j}$ may generate expectations of dividend increase and thus when the increase is announced, its effect on price is smaller, $a_{9}<0$. $R E P_{j}$ is found by Grinstein and Michaely (2004) to be related to $I N S T_{j}$. Its effect on $C A R_{j}$ is unclear. If stock repurchases provide information that reduces the information content of dividends, $a_{10}<0$. But if stock repurchase are considered substitutes for dividend increases, we expect $a_{10}>0$, i.e., a greater surprise when dividend is increased.

The model includes time dummy variables: $Q T R_{n j}$ equals 1 if event $j$ is in quarter $n$ and zero otherwise. This controls for possible variations over time in average $C A R$ due to time-related factors (e.g., taxes and investors' sentiment). $I N D_{m j}$ is an industry dummy variable that equals 1 if the firm that made announcement $j$ is in industry $m$, using twodigit SIC, and zero otherwise; our data include 57 industries in the pooled regressions and 13 major industry groups (following Lo and Wang (2001)) in the Fama-Macbeth 
regressions, which are done annually on a smaller number of observations. The sample consists of 4,507 cases that satisfy the data requirements.

The model is estimated for both $C A R_{j}$ (days 0 to +1 ) and $C A R 13_{j}$ (days -11 to +1 ) in two versions. The reduced model includes only variables whose coefficients are significant for $C A R_{j}$ and $C A R 13_{j}$, and the full model includes all variables.

\section{INSERT TABLE 3}

Hypothesis 1 is strongly supported by the results, presented in Table 3, Panel A. The coefficient of INST $T_{j}, a_{2}$, is negative and significant for both $C A R$ and $C A R 13$, for both models and for both estimation methods. Also, the coefficient of $S P 500_{j}$ has the opposite sign, as expected. The other variables in the reduced model have the expected coefficients. In the full model, the coefficients of the added variables are insignificantly different from zero for the model with $C A R_{j}$. The effect of $S I Z E N_{j}$ is insignificant for $C A R 13_{j}$, but then $I L L I Q_{j}$ has a more significant effect. $L T V O L_{j}$ has the expected positive effect but it is insignificant for $C A R_{j}$.

As a robustness check on the effect of institutional holdings, $I N S T_{j}$ is replaced by an ordinal measure of institutional holdings, INSTORD ${ }_{j}$, which is insensitive to outliers and clustering of values of $I N S T_{j}$. In each quarter, we rank stocks with dividend increase announcements by their institutional holdings and divide them into 10 groups. Then, $I N S T O R D_{j}=1,2, \ldots, 10$, where 10 is the group with the highest $I N S T_{j}$. The results are qualitatively similar. For example, when $I N S T O R D_{j}$ replaces $I N S T_{j}$ in the reduced-model version of $(5-1), a_{2}=-0.0004(t=2.20)$ for $C A R$ and $a_{2}=-0.0013(t=3.17)$ for $C A R 13$. The signs and statistical significance of the other variables remain unchanged. 
In another robustness check, we examine the effect of a possible endogeneity of institutional holdings, re-estimating model (5) by the instrumental variables method. The instrumental variables that may affect the level of institutional holdings are $L T Y L D$ (to account for a possible effect of dividend policy on INST), LTVOL, SIZEN, SP500, PRC (stock price at the end of the month before the dividend announcement, in logarithm), $A G E$, momentum (return over the past 3 months), market-to-book ratio and stock turnover. We obtain that in the reduced-model version of $(5-1), a_{2}=-0.029(t=3.67)$ for $C A R$ and $a_{2}=-0.095(t=5.76)$ for $C A R 13$, consistent with our hypothesis.

The second test of Hypothesis 1 examines the effect of institutional holdings on the dividend response coefficient, which measures the price impact of the magnitude of dividend increases. We estimate the following pooled regression:

$$
\begin{aligned}
\text {CAR }_{j}= & b_{0}+b_{1} \text { DDIVY }_{j}+b_{2} \text { DDIVY }_{j} \cdot I N S T_{j}+b_{3} \text { DDIVY }_{j}{\text { SP } 500_{j} a_{4} L T Y L D_{j}} \\
& +b_{5} \text { SIZEN }_{j}+b_{6} A G E_{j}+b_{7} L T V O L_{j}+b_{8} I L L I Q_{j}+b_{9} R O A_{j}+b_{10} R E P_{j} \\
& +\sum_{m=1}^{56} b_{11 m} I N D_{m j}+\sum_{n=1}^{70} b_{12 n} Q T R_{n j}+e_{j} .
\end{aligned}
$$

The corresponding Fama-Macbeth regressions for each year $y$ are

$$
\begin{aligned}
C A R_{j y}= & b_{0 y}+b_{1 y} D D I V Y_{j y}+b_{2 y} D D I V Y_{j y} \cdot I N S T_{j y}+b_{3 y} D D I V Y_{j y} \cdot S P 500_{j y} \\
& +b_{4 y} L T Y L D_{j y}+b_{5 y} S I Z E N_{j y}+b_{6 y} A G E_{j y}+b_{7 y} L T V O L_{j y}+b_{8 y} I L L I Q_{j y} \\
& +b_{9 y} R O A_{j y}+b_{10 y} R E P_{j y}+\sum_{m=1}^{12} b_{11 m y} I N D_{m j y}+e_{j y}
\end{aligned}
$$

By Hypothesis 1, institutional holdings should reduce the dividend response coefficient, i.e., $b_{2}<0$. And, since some institutional holdings of S\&P 500 stocks are passive, we expect $b_{3}>0$. 
The estimation results of model (6), presented in Table 3, Panel B, again support Hypothesis 1 in all models: $b_{2}$ is negative and significant. Also, $b_{3}$ is positive and significant. Again, as a robustness check, we re-estimate model (6-1) replacing $I N S T_{j}$ by the ordinal variable $I N S T O R D_{j}=1,2, \ldots 10$. Then, $b_{2}=-0.107(t=2.72)$ for $C A R$ and $b_{2}=-0.220(t=2.71)$ for $C A R 13$ in the reduced version of model (6-1).

As another robustness check, we control for analysts coverage of firms that announce dividend increases, since such coverage also affects the information available to investors about the stock. We add to model (6-1) DDIVY $Y_{j} \cdot A^{\prime} A L Y S T S_{j}$, where ANALYSTS is the number of analysts' estimates in the consensus earnings estimate prior to the announcement of dividend change (in logarithms; the data source is $\mathrm{I} / \mathrm{B} / \mathrm{E} / \mathrm{S}$ ). The sample size is then reduced by $26 \%$ to 3377 events. The estimated coefficient of $D D I V Y_{j} \cdot A N A L Y S T S_{j}$ is $0.26(t=1.94)$. Importantly, the coefficient of $D D I V Y_{j} \cdot I N S T_{j}$ remains negative, -2.86 , with $t=3.90$, highly significant.

\section{Trading by institutional investors around dividend increase announcements}

Institutional investors with favorable information about a firm may buy its stock well before this information becomes public through a dividend increase announcement by the firm. Therefore, this information will have been incorporated in the stock price by the time the dividend increase is announced, and consequently the price reaction to the news will be smaller, as documented in Section II. Hypothesis 2 tests whether such a pattern of trading exists. We expect that institutional investors increase their holdings in a firm before it announces a dividend increase, and after the information becomes public their acquisition of the firm's stock subsides or even reversed (i.e., they sell the stock). 
We do an event study-type analysis of changes in institutional holdings around the quarter when the dividend increase in announced. Excess change in institutional holdings is measured by $E \Delta I N S T_{j}=\Delta I N S T_{j}-\Delta I N S T m$, where $\Delta I N S T_{j}$ is the quarterly change in $I N S T_{j}$ and $\triangle I N S T m$ is the quarterly change in INST for all firms for which data are available in the quarter. Because of positive skewness, we do the transformation $\log (1+$ $E \Delta I N S T_{j}$ ), which we still call $E \Delta I N S T_{j}$. We expect that $E \Delta I N S T_{j}>0$ in quarters $\mathrm{q}=-2$ and $\mathrm{q}=-1$, while in quarter $\mathrm{q}=+1$ the rise in $I N S T_{j}$ should disappear or $I N S T_{j}$ should even decline if institutions scale back their holdings after they no longer have information advantage. Then, $E \Delta I N S T_{j} \leq 0$. At the end of $\mathrm{q}=0$, the quarter when the dividend increase is announced, $E \Delta I N S T_{j}$ should be small or zero.

\section{INSERT TABLE 4}

The results in Table 4 are consistent with Hypothesis $2 .{ }^{16}$ In column (a), the means of $E \Delta I N S T_{j}$ are positive and highly significant in the two quarters before the dividend increase announcement, whereas mean $E \Delta I N S T_{j}$ is zero in $\mathrm{q}=+1$. In $\mathrm{q}=0$, $E \Delta I N S T_{j}$ is positive but smaller than in the previous quarter. By the tests in column (b), the mean $E \Delta I N S T_{j}$ after the dividend announcement $(\mathrm{q}=+1)$ is significantly smaller than the mean $E \Delta I N S T_{j}$ before the announcement ( $\mathrm{q}=-2$ and in particular $\mathrm{q}=-1$ ), while the difference from quarter $\mathrm{q}=0$ is marginally insignificant. This is consistent with our hypothesis: institutions buy aggressively in the quarters before the dividend increase announcement but not afterwards.

\footnotetext{
${ }^{16}$ The number of cases in this test rises, between 4590 and 4746, because we are not constrained by data availability on other variables; but other data limitations constrain the analysis to 68-70 quarters.
} 
Column (c) presents the means of $E \Delta I N S T_{j}$ weighted by $I N S T_{j}^{0}$, the institutional holdings at the end of $\mathrm{q}=0$. We expect that our hypothesis will be more pronounced in firms with high institutional holdings, about which more information is generated. Indeed, the results in Table 3 have shown that in firms with larger $I N S T_{j}$, less new information is generated by dividend increase announcements and consequently the price increase is smaller. The results in column (c) show that while the (weighted) mean of $E \Delta I N S T_{j}$ is positive and highly significant in quarters $\mathrm{q}=-2$ and $\mathrm{q}=-1$, it is practically zero in $\mathrm{q}=0$ and it turns slightly negative in $\mathrm{q}=+1$ which follows the announcement.

Column (d) presents test results of the null hypotheses that the proportion of firms with $E \Delta I N S T_{j}>0$ is not different from 0.50 , a chance result, against the alternative hypothesis that the proportion is greater than 0.50 . We obtain that the null hypothesis is rejected for quarters $\mathrm{q}=-2, \mathrm{q}=-1$ and $\mathrm{q}=0$, but not for quarter $\mathrm{q}=+1$. The result is particularly strong for quarter $\mathrm{q}=-1$. That is, $I N S T_{j}$ rises well before the dividend increase is announced but afterwards there is no systematic excess change in $I N S T_{j}$.

Finally, we present in columns (e) and (f) the mean of the quarters' mean $E \Delta I N S T_{j}$. We obtain again that while $E \Delta I N S T_{j}$ is large and significant particularly in quarter $\mathrm{q}=-1$, it is practically zero in quarter $\mathrm{q}=+1$. This pattern is strongly pronounced for the $I N S T_{j}^{0}$-weighted mean of $E \Delta I N S T_{j}$ which is positive and significant for both $\mathrm{q}=-2$ and $\mathrm{q}=-1$ and practically zero for quarters $\mathrm{q}=0$ and $\mathrm{q}=+1$.

We also estimate in a regression model for each quarter how $\Delta I N S T_{j}$ changes as a function of $I N S T_{j}^{0}$, controlling for the effects of $S P 500_{j}, S I Z E N_{j}, L T Y L D_{j}$ and $L T V O L_{j}$ as well as for time variation of mean $\Delta I N S T_{j}$ (using quarter dummies) and for industries. We assume that in firms with larger $I N S T_{j}^{0}$ the institutional trading activity is more 
pronounced. The results ${ }^{17}$ are as follows. During quarters $\mathrm{q}=-2$ and $\mathrm{q}=-1$, the coefficient of $\triangle I N S T_{j}$ on $I N S T_{j}^{0}$ is positive and significant, meaning that in such firms there is more active buying of stocks before the dividend increase announcements. In quarters $\mathrm{q}=0$ and $\mathrm{q}=+1$, the coefficient is negative and significant, that is, after the information about the firm becomes public, institutional holdings are scaled back more in firms with larger $I N S T_{j}^{0}$.

The results are thus consistent with our Hypothesis 2: institutional investors, which are better informed about well-performing firms before these firms announce dividend increases, use their information to trade well before the news become public. Because of their early buying, by the time that the dividend increase is announced, part of the favorable information is already incorporated in the stock price. This explains the results that the price reaction $(C A R)$ to this information is smaller (Section III.C).

\section{The effect of institutional holdings on the firms' dividend decisions}

We now turn to Hypothesis 3. If larger institutional holdings reduce the positive price impact of dividend increase announcements, then given that dividends are costly, firms with high institutional holdings should be less likely to raise dividends. We test this hypothesis by examining the effect of institutional holdings on the likelihood of dividend increases. We estimate the following ordered probit model (following Christensen and Prabhala (1995)):

\footnotetext{
${ }^{17}$ The results are available upon request.
} 


$$
\begin{aligned}
L_{j}= & \theta_{0}+\theta_{1} I N S T_{j}+\theta_{2} S P 500_{j}+\theta_{3} L_{T Y L D_{j}}+\theta_{4} \text { DIFYLD }_{j}+\theta_{5} \text { SIZEN }_{j}+\theta_{6} P R C_{j} \\
& +\theta_{7} L T V O L_{j}+\sum_{m=1}^{56} \theta_{8 m} I N D_{m j}+\sum_{n=1}^{70} \theta_{9 n} \text { OTR }_{n j}+e_{j} .
\end{aligned}
$$

The corresponding annual Fama-Macbeth regression model (7-2) has 13 (aggregated) industry dummy variables instead of 56 and does not include the quarterly dummy variables. $L_{j}$ equals $+1,0$ or -1 if the dividend announcement $j$ is an increase, no change or decrease (respectively) compared to the dividend in the previous quarter. INST $T_{j}$ is the institutional holdings in the quarter before the dividend announcement. $D I F Y L D_{j}=$ $S T Y L D_{j}-L T Y L D_{j}$ is the difference between the short term and the long term dividend yield. ${ }^{18}$ STYLD is the most recent quarterly dividend divided by the stock price at the end of the month prior to the dividend announcement, multiplied by four (annualized). $P R C_{j}$ is the stock price (in logarithm) at the end of the quarter before the dividend announcement. Notably, this estimation uses all dividend announcements for which data on $I N S T_{j}$ are available, including those with no change in dividends, which are by far the great majority of all dividend announcements.

\section{INSERT TABLE 5}

By Hypothesis 3 we expect $\theta_{1}<0$. The results, presented in Table 5, support our hypothesis: the coefficient of $I N S T_{j}$ is negative and significant. That is, higher institutional holdings reduce the probability of subsequent dividend increases, which means that the dividend decision of firms is affected in part by the identity of their investors. This finding is consistent with our main hypothesis in this study: the

\footnotetext{
${ }^{18}$ We eliminate 9 announcements, $0.02 \%$ of the sample, with DIFYLD $>20 \%$.
} 
phenomenon of disappearing dividends in the U.S. is tied to the increase in institutional holdings of stocks.

E. Institutional holdings and stock price reaction to dividend surprises

It could be argued that the relationship between $C A R_{j}$ and $I N S T_{j}$ (measured in the quarter before the dividend is announced) documented in section III.B., is tainted by our findings in section III.D. that the likelihood of dividend changes is affected in part by $I N S T_{j}$. A similar problem was considered by Christensen and Prabhala (1995) where a structural variable may affect both the likelihood of a dividend increase and the price reaction to the surprise about the dividend increase. We therefore repeat our estimations of the effect of $I N S T_{j}$ on $C A R_{j}$ after having controlled for the effect of $I N S T_{j}$ on the dividend surprise. DIVSURP is obtained from the ordered probit model (7) as the expectation of the structural residual conditional on the event (see Christensen and Prabhala, 1995. We analyze the events of dividend increases and estimate the following models, which are similar to models (5) and (6), with $D I V S U R P_{j}$ replacing $D D I V Y_{j}$ :

$$
\begin{aligned}
& C A R_{j}=\gamma_{0}+\gamma_{1} \text { DIVSURP }_{j}+\gamma_{2} I N S T_{j}+\gamma_{3}{\text { SP } 500_{j}}+\gamma_{4} \text { SIZEN }_{j}+\gamma_{5} L_{T Y L D} \\
& +\sum_{m=1}^{56} \gamma_{6 m} I N D_{m j}+\sum_{n=1}^{70} \gamma_{7 n} Q T R_{n j}+e_{j} . \\
& \text { CAR }_{j}=\delta_{0}+\delta_{1} \text { DIVSURP }_{j}+\delta_{2} \text { DIVSURP }_{j} \cdot I N S T_{j}+\delta_{3} \text { DIVSURP }_{j} \cdot{\text { SP } 50 O_{j}} \\
& +\delta_{4} \operatorname{SIZEN}_{j}+\delta_{5} L T Y L D_{j}+\sum_{m=1}^{56} \delta_{6 m} I N D_{m j}+\sum_{n=1}^{70} \delta_{7 n} Q T R_{n j}+e_{j} .
\end{aligned}
$$

The corresponding annual Fama-Macbeth models, (8-2) and (9-2), do not include quarterly dummies and use13 dummy variables for the aggregated industrial groups.

\section{INSERT TABLE 6}


Hypothesis 1, that implies $\gamma_{2}<0$ and $\delta_{2}<0$, is strongly supported by the results in Table 6. Both $\gamma_{2}$ and $\delta_{2}$ are negative and highly significant in all models. The greater the institutional holdings, the smaller is the information in reaction to dividend increase announcements. The coefficient of $S P 500_{j}$ has the opposite sign of that of $I N S T_{j}$, as expected, although it is not always significant.

Most of our results on the effects of institutional holdings accommodate an alternative explanation. Institutions may have superior ability to monitor firms and thus reduce agency costs. Dividends are also suggested to have a monitoring role by reducing free cash flows and provide subjecting managers to screening by the market when they need to raise capital (Easterbrook, 1984). If monitoring by institutions substitutes for monitoring by dividends, we should obtain the results that are documented above: a decline in the stock price reaction to dividend increase announcements, and a decline in the propensity of firms to raise dividends. However, some of our results pertain only to the explanation associated with the information content of dividends and the superior information possessed by institutional investors: $C A R$ for dividend decrease announcements (which convey information but have no monitoring implications) also show a decline over time, and we show that institutions trade on their information that is reflected in subsequent dividend increase announcements.

\section{Conclusion}

In this paper we propose the following. 
(1) The "disappearing dividend" phenomenon is partly due to a decline in the information content of dividend news - dividend increases and decreases. If dividends provide investors with less information about the firm's value, then given that they are costly, firms may refrain from initiating them or from raising them and may even reduce them.

(2) Dividend announcements are becoming less informative due to the increase in stockholdings by institutional investors that are more sophisticated and informed than average individual investors. Thus, by the time the dividend news is announced, the information that it is intended to convey is already incorporated in the stock price. Consequently, the disappearing dividends are partly a result of the increase in institutional holdings.

We test each of the two hypotheses in a number of ways and the results are consistent with our hypotheses. We observe a strong trend of decline in stock price reaction to dividend change announcements since the late 1970s that coincides with the pattern of decline in dividends that also began at that time.

In a cross-sectional analysis we find that the price reaction to dividend news is weaker in stocks with high institutional holdings. We also observe that institutional investors increase their holdings in firms that subsequently raise dividends even two quarters before the announcement but stop doing that after the dividend announcement, especially in firms with large institutional holdings. And finally, firms with high institutional holdings are less likely to raise their dividends. Altogether, our analysis shows that the disappearance of dividends reflects the declining role of dividends as a means to convey information, which is a result of the increase in institutional holdings. 


\section{References}

Acharya, V., and L. H. Pedersen. "Asset Pricing with Liquidity Risk.” Journal of Financial Economics, forthcoming (2004).

Aharony, J., and I. Swary. "Quarterly Dividend and Earnings Announcements and Stockholders Returns: An Empirical Analysis.” Journal of Finance, 35 (1980), 1-12.

Alangar, S.; C. T. Bathala; and R. P. Rao. "The Effect of Institutional Interest on the Information Content of Dividend-Change Announcement." Journal of Accounting Research, 22 (1999), 429-448.

Allen, F., and R. Michaely. "Payout Policy." In North Holland Handbooks of Economics, G. Constantinides, M. Harris, and R. Stulz, eds. forthcoming (2003).

Amihud, Y. "Illiquidity and Stock Returns: Cross-Section and Time Series Effects." Journal of Financial Markets, 5 (2002), 31-56.

Amihud, Y, and M. Murgia, "Dividends, Taxes and Signaling: Evidence from Germany." Journal of Finance, 52 (1997), 397- 408.

Anderson, R. C., and D. S. Lee. "Ownership Studies: The Data Source Matters." Journal of Financial and Quantitative Analysis, 32 (1997), 311-329.

Baker, M., and J. Wurgler. "Why are Dividends Disappearing? An Empirical Analysis." Working paper, Stern School of Business, New York Univ. (2002).

Banerjee, S.; V. A. Gatchev; and P. A. Spindt. "To Pay or not to Pay? The Dividend Dilemma of the Liquid Firm." Working paper, Tulane Univ. (2003).

Barber, B. M.; Y-T Lee; Y-J Liu; and T. Odean, 2004, Who Gains from Trade? Evidence from Taiwan. Working paper.

Bartov, E.; S. Radhakrishnan; and I. Krinsky. "Investor Sophistication and Patterns in Stock Returns after Earnings Announcements.” Accounting Review, 75 (2000), 43-63.

Bernheim, B. D., and A. Wantz. "A Tax-Based Test of the Dividend Signaling Hypothesis." American Economic Review, 85 (1995), 532-551.

Bhattacharya, S. "Imperfect Information, Dividend Policy, and 'The Bird in the Hand' Fallacy.” Bell Journal of Economics, 10 (1979), 259-270.

Bushee, B. J., and C. F. Noe. "Corporate Disclosure Practices, Institutional Investors, and Stock Return Volatility.” Journal of Accounting Research, 38 (2000), 271-302. 
Chakravarty, S. "Stealth Trading: Which Traders' Trades Move Stock Prices?" Journal of Financial Economics, 61 (2001), 289-307.

Chen, H., N. Jegadeesh, and R. Wermers. "The Value of Active Mutual Fund Management: An Examination of the Stockholdings and Trades of Fund Managers." Journal of Financial and Quantitative Analysis, 35 (2000), 343-368.

Chidambaran, N. K., and K. John. "Managerial Compensation, Voluntary Disclosure and Large Shareholder Monitoring.” Working Paper, New York Univ. (2001).

Christensen, B., and N. R. Prabhala. "Expectation and the Cross-Section of Dividend Announcement Effects." Working paper, New York Univ. (1995).

DeAngelo, H.; L. DeAngelo; and D. J. Skinner. "Are Dividends Disappearing? Dividend Concentration and the Consolidation of Earnings." Journal of Financial Economics, forthcoming (2004).

Dennis, P. J., and J. Weston. "Who's Informed? An Analysis of Stock Ownership and Informed Trading.” Working paper, Univ. of Virginia (2001).

Easterbrook, F. H. "Two Agency-Cost Explanations of Dividends." American Economic Review, 84 (1984), 650-659.

Fama, E. F., and K. R. French. "Disappearing Dividends: Changing Firm Characteristics or Lower Propensity to Pay?" Journal of Financial Economics, 60 (2001), 3-44.

Gillan, S. L., and L. T. Starks. "Institutional Investors, Corporate Ownership and Corporate Governance: Global Perspectives." Working paper, TIAA-CRAF and Univ. of Texax-Austin (2001).

Gompers, P. A., and A. Metrick. "Institutional Investors and Equity Prices." Quarterly Journal of Economics, 116 (2001), 229-259.

Grullon, G., and R. Michaely. "Dividends, Share Repurchase and the Substitution Hypothesis.” Journal of Finance, 57 (2002), 1649-1684.

Grullon, G., R. Michaely and B. Swaminathan. "Are Dividend Changes a Sign of Firm Maturity?” Journal of Business, 75 (2002), 387-424.

Handjinicolaou, G., and A. Kalay. "Wealth Redistribution or Changes in Firm Value: An Analysis of Returns to Bondholders and Stockholders around Dividend Announcements." Journal of Financial Economics, 13 (1984), 35-63.

Hasbrouck, J. "Trading Costs and Returns for US Equities: Evidence from Daily Data." Working paper, New York Univ. (2004). 
Healy, P. M.; A. P. Hutton; and K. G. Palepu. "Stock Performance and Intermediation Changes Surrounding Increases in Disclosure." Contemporary Accounting Research, 16 (1999), 485-520.

Jiambalvo, J.; S. Rajgopal; and M. Venkatachalam. "Institutional Ownership and the Extent to Which Stock Prices Reflect Future Earnings." Contemporary Accounting Research, 19 (2002), 117-145.

John, K.; and J. Williams. "Dividends, Dilution, and Taxes: A Signaling Equilibrium." Journal of Finance, 40 (1985), 1053-1070.

Lo, A. W., and J. Wang. "Trading Volume: Implications of an Intertemporal Capital Asset Pricing Model.” Working paper, Massachusetts Institute of Technology (2001).

Miller, M., and K. Rock. "Dividend Policy under Asymmetric Information." Journal of Finance, 40 (1985), 1031-1051.

Newey, W. K., and K. D. West. "A Simple, Positive Semi-Definite Heteroskedasticity and Autocorrelation Consistent Covariance Matrix." Econometrica, 55 (1987), 703-708.

Ofer, A. R., and D. R. Siegel. "Corporate Financial Policy, Information, and Market Expectations: An Empirical Investigation of Dividends.” Journal of Finance, 42 (1987), 889-911.

Ofer, A. R., and A. V. Thakor. "A Theory of Stock Price Responses to Alternative Corporate Cash Disbursement Methods: Stock Repurchases and Dividends." Journal of Finance, 42 (1987), 365-406.

Prabhala, N. R. "Conditional Methods in Event Studies and an Equilibrium Justification for Standard Event-Study Procedures." Review of Financial Studies, 10 (1997), 1-38.

White, H. L. "A Heteroskedasticity-Consistent Covariance Matrix Estimator and a Direct Test for Heteroskedasticity.” Econometrica, 48 (1980), 817-838. 
Table 1

Regressions of $\alpha 1_{y}$ on annual time series, $1963-2000$

\begin{tabular}{|c|c|c|c|c|c|c|c|c|}
\hline & (a) & (b) & (c) & (d) & (e) & (f) & (g) & (h) \\
\hline Const. & $\begin{array}{l}0.765 \\
(3.53) \\
\end{array}$ & $\begin{array}{l}1.838 \\
(9.16)\end{array}$ & $\begin{array}{c}1.323 \\
(10.17\end{array}$ & $\begin{array}{l}0.593 \\
(1.04)\end{array}$ & $\begin{array}{c}1.961 \\
(8.85)\end{array}$ & $\begin{array}{l}7.199 \\
(2.29)\end{array}$ & $\begin{array}{l}2.372 \\
(6.53)\end{array}$ & $\begin{array}{l}73.13 \\
(3.66)\end{array}$ \\
\hline TAX & $\begin{array}{l}0.041 \\
(3.46) \\
\end{array}$ & & & & & & & \\
\hline ILLIQ & & $\begin{array}{l}0.380 \\
(3.28)\end{array}$ & & & & & & \\
\hline$D N D S$ & & & $\begin{array}{l}0.009 \\
(1.92) \\
\end{array}$ & & & & & \\
\hline$R O A$ & & & & $\begin{array}{c}0.013 \\
(1.15)\end{array}$ & & & & \\
\hline$R E P$ & & & & & $\begin{array}{r}-66.10 \\
(3.48)\end{array}$ & & & \\
\hline$A G E$ & & & & & & $\begin{array}{r}-1.977 \\
(1.87) \\
\end{array}$ & & \\
\hline INST & & & & & & & $\begin{array}{l}-0.030 \\
(2.91)\end{array}$ & \\
\hline$y$ & & & & & & & & $\begin{array}{l}-0.036 \\
(3.60) \\
\end{array}$ \\
\hline$R^{2}$ & 0.24 & 0.20 & 0.04 & 0.03 & 0.30 & 0.09 & 0.19 & 0.31 \\
\hline$D W$ & 1.66 & 1.79 & 1.55 & 1.50 & 1.66 & 1.59 & 1.71 & 2.03 \\
\hline
\end{tabular}

The dependent variable $\alpha l_{y}$ is the dividend response coefficient for year $y$, obtained by regressing $C A R_{j y}$ on the dividend increase $D D I V Y_{j y}$ across firms in year $y . T A X_{y}$ is the difference between the tax rates on dividends and on capital gains. ILLIQ $Q_{y}$ is market illiquidity (in logarithm), the ratio of daily absolute return to dollar volume in year $y$ (averaged over all days and across all stocks; Amihud (2002)). $D N D S_{y}$ is the spread between the $\mathrm{Q}$ values of dividend- and non-dividend-paying stocks (Baker and Wurgler (2004)). $R O A_{y}$ is the average $R O A$ in year $y$ for dividend-paying firms. $R E P_{y}$, the extent of stock repurchase, is the proportion the dollar amount of equity purchase out of beginning-of-year market value of equity (the series begins in 1971). $A G E_{y}$ is the age (in $\log$ years) of dividend paying firms in year $y$. INST is the average institutional holdings in year $y$. Data on TAX are missing for 1963 and 1965. Data on REP begin in 1971. 
Table 2

Statistics on institutional holdings over time

\begin{tabular}{|c|c|c|c|}
\hline & \multirow{2}{*}{ Number of } & \multicolumn{2}{|c|}{ INST } \\
\cline { 3 - 4 } Year & cases & Mean & Median \\
\hline 1980 & 283 & 0.2901 & 0.2946 \\
\hline 1981 & 373 & 0.3150 & 0.3320 \\
\hline 1982 & 265 & 0.3215 & 0.3366 \\
\hline 1983 & 259 & 0.3403 & 0.3575 \\
\hline 1984 & 335 & 0.3567 & 0.3713 \\
\hline 1985 & 264 & 0.3918 & 0.4025 \\
\hline 1986 & 198 & 0.4264 & 0.4350 \\
\hline 1987 & 253 & 0.4365 & 0.4514 \\
\hline 1988 & 326 & 0.4601 & 0.4807 \\
\hline 1989 & 315 & 0.4603 & 0.4754 \\
\hline 1990 & 261 & 0.4836 & 0.5006 \\
\hline 1991 & 203 & 0.4825 & 0.4909 \\
\hline 1992 & 228 & 0.4823 & 0.5091 \\
\hline 1993 & 195 & 0.4885 & 0.5296 \\
\hline 1994 & 156 & 0.4983 & 0.5063 \\
\hline 1995 & 323 & 0.5104 & 0.5453 \\
\hline 1996 & 309 & 0.4934 & 0.5075 \\
\hline 1997 & 231 & 0.5131 & 0.5264 \\
\hline 1998 & 130 & 0.5351 & 0.5447 \\
\hline
\end{tabular}

The table presents statistics on INST, the proportion of the firm's stock held by institutional investors. The observations are for firms that announce dividend increase. The variable INST is for the end of the quarter when dividend increase is announced. Data are missing for three quarters, 4Q1993-2Q1994. The averages for the respective years are over the quarters for which data are available. 
Table 3

The effect of institutional holdings on stock price reaction to dividend increases

Panel A: Models (5-1) and (5-2).

\begin{tabular}{|c|c|c|c|c|c|c|c|c|}
\hline \multirow[b]{2}{*}{ Variable } & \multicolumn{4}{|c|}{ Pooled regressions } & \multicolumn{4}{|c|}{ Fama-Macbeth regressions } \\
\hline & $C A R$ & CAR13 & $C A R$ & CAR13 & $C A R$ & CAR13 & $C A R$ & CAR13 \\
\hline $\begin{array}{l}a_{1} \\
D D I V Y_{j}\end{array}$ & $\begin{array}{c}1.03 \\
(7.60) \\
\end{array}$ & $\begin{array}{c}1.76 \\
(6.27) \\
\end{array}$ & $\begin{array}{c}0.98 \\
(7.15) \\
\end{array}$ & $\begin{array}{c}1.64 \\
(5.75) \\
\end{array}$ & $\begin{array}{c}1.10 \\
(4.13) \\
\end{array}$ & $\begin{array}{c}1.65 \\
(4.40) \\
\end{array}$ & $\begin{array}{c}1.26 \\
(3.59) \\
\end{array}$ & $\begin{array}{c}2.41 \\
(3.96) \\
\end{array}$ \\
\hline $\begin{array}{l}a_{2} \\
I N S T_{j}\end{array}$ & $\begin{array}{l}-0.007 \\
(2.28) \\
\end{array}$ & $\begin{array}{l}-0.019 \\
(3.06) \\
\end{array}$ & $\begin{array}{l}-0.006 \\
(1.93) \\
\end{array}$ & $\begin{array}{l}-0.016 \\
(2.52) \\
\end{array}$ & $\begin{array}{l}-0.007 \\
(2.75) \\
\end{array}$ & $\begin{array}{l}-0.018 \\
(3.24) \\
\end{array}$ & $\begin{array}{l}-0.005 \\
(2.00) \\
\end{array}$ & $\begin{array}{l}-0.013 \\
(2.42) \\
\end{array}$ \\
\hline $\begin{array}{l}a_{3} \\
S P 500_{j}\end{array}$ & $\begin{array}{l}0.003 \\
(2.15) \\
\end{array}$ & $\begin{array}{l}0.007 \\
(2.46) \\
\end{array}$ & $\begin{array}{l}0.003 \\
(2.02) \\
\end{array}$ & $\begin{array}{l}0.006 \\
(2.07) \\
\end{array}$ & $\begin{array}{l}0.002 \\
(1.68) \\
\end{array}$ & $\begin{array}{l}0.005 \\
(1.99) \\
\end{array}$ & $\begin{array}{l}0.002 \\
(1.26) \\
\end{array}$ & $\begin{array}{l}0.001 \\
(0.17) \\
\end{array}$ \\
\hline $\begin{array}{l}a_{4} \\
S I Z E N_{j}\end{array}$ & $\begin{array}{l}-0.001 \\
(3.38) \\
\end{array}$ & $\begin{array}{l}-0.003 \\
(3.15) \\
\end{array}$ & $\begin{array}{l}-0.001 \\
(2.60) \\
\end{array}$ & $\begin{array}{l}-0.002 \\
(1.69) \\
\end{array}$ & $\begin{array}{l}-0.001 \\
(2.54) \\
\end{array}$ & $\begin{array}{l}-0.001 \\
(2.45) \\
\end{array}$ & $\begin{array}{l}-0.001 \\
(2.11) \\
\end{array}$ & $\begin{array}{l}0.000 \\
(0.12) \\
\end{array}$ \\
\hline $\begin{array}{l}a_{5} \\
L T Y L D_{j}\end{array}$ & $\begin{array}{c}0.12 \\
(3.42) \\
\end{array}$ & $\begin{array}{c}0.29 \\
(3.98) \\
\end{array}$ & $\begin{array}{c}0.14 \\
(3.72)\end{array}$ & $\begin{array}{c}0.32 \\
(4.14)\end{array}$ & $\begin{array}{c}0.12 \\
(4.85) \\
\end{array}$ & $\begin{array}{c}0.16 \\
(1.81) \\
\end{array}$ & $\begin{array}{l}0.143 \\
(4.22) \\
\end{array}$ & $\begin{array}{c}0.18 \\
(2.11) \\
\end{array}$ \\
\hline $\begin{array}{l}a_{6} \\
A g e_{j}\end{array}$ & & & $\begin{array}{c}-0.0001 \\
(0.18)\end{array}$ & $\begin{array}{c}-0.0002 \\
(0.16) \\
\end{array}$ & & & $\begin{array}{l}0.001 \\
(0.92) \\
\end{array}$ & $\begin{array}{l}0.002 \\
(1.40) \\
\end{array}$ \\
\hline $\begin{array}{l}a_{7} \\
L T V O L_{j}\end{array}$ & & & $\begin{array}{l}0.003 \\
(1.57) \\
\end{array}$ & $\begin{array}{c}0.008 \\
(2.03) \\
\end{array}$ & & & $\begin{array}{l}0.004 \\
(1.56) \\
\end{array}$ & $\begin{array}{l}0.009 \\
(1.44) \\
\end{array}$ \\
\hline $\begin{array}{l}a_{8} \\
I L L I Q_{j}\end{array}$ & & & $\begin{array}{l}0.002 \\
(0.60) \\
\end{array}$ & $\begin{array}{l}0.010 \\
(1.87) \\
\end{array}$ & & & $\begin{array}{l}0.011 \\
(1.76) \\
\end{array}$ & $\begin{array}{l}0.027 \\
(1.89) \\
\end{array}$ \\
\hline $\begin{array}{l}a_{9} \\
R O A_{j} \\
\end{array}$ & & & $\begin{array}{l}0.005 \\
(0.78) \\
\end{array}$ & $\begin{array}{l}-0.017 \\
(1.29) \\
\end{array}$ & & & $\begin{array}{l}0.004 \\
(0.76) \\
\end{array}$ & $\begin{array}{l}-0.011 \\
(0.70) \\
\end{array}$ \\
\hline $\begin{array}{l}a_{10} \\
R E P_{j}\end{array}$ & & & $\begin{array}{l}0.008 \\
(0.66) \\
\end{array}$ & $\begin{array}{c}-0.020 \\
(0.81) \\
\end{array}$ & & & $\begin{array}{l}0.013 \\
(0.72) \\
\end{array}$ & $\begin{array}{l}0.011 \\
(0.25) \\
\end{array}$ \\
\hline $\begin{array}{l}\text { Adjusted } \\
R^{2}\end{array}$ & $7.2 \%$ & $7.2 \%$ & $7.3 \%$ & $7.4 \%$ & $11.76 \%$ & $9.60 \%$ & $14.36 \%$ & $13.03 \%$ \\
\hline No. Obs & 4507 & 4507 & 4237 & 4237 & 4507 & 4507 & 4237 & 4237 \\
\hline
\end{tabular}


Panel B: Models (6-1) and (6-2)

\begin{tabular}{|c|c|c|c|c|c|c|c|c|}
\hline \multirow[b]{2}{*}{ Variable } & \multicolumn{4}{|c|}{ Pooled regressions } & \multicolumn{4}{|c|}{ Fama-Macbeth regressions } \\
\hline & $C A R$ & CAR 13 & $C A R$ & CAR 13 & $C A R$ & CAR 13 & $C A R$ & CAR13 \\
\hline $\begin{array}{l}b_{1} \\
D D I V Y_{j}\end{array}$ & $\begin{array}{c}1.41 \\
(7.41) \\
\end{array}$ & $\begin{array}{c}2.49 \\
(6.34) \\
\end{array}$ & $\begin{array}{c}1.33 \\
(6.81) \\
\end{array}$ & $\begin{array}{c}2.24 \\
(5.53) \\
\end{array}$ & $\begin{array}{c}1.62 \\
(4.14) \\
\end{array}$ & $\begin{array}{c}2.62 \\
(4.53)\end{array}$ & $\begin{array}{c}1.69 \\
(3.05)\end{array}$ & $\begin{array}{c}3.39 \\
(4.07)\end{array}$ \\
\hline $\begin{array}{l}b_{2} \\
D^{\prime} D I V Y_{j} \\
I N S T_{j}\end{array}$ & $\begin{array}{c}-1.79 \\
(3.23)\end{array}$ & $\begin{array}{c}-3.41 \\
(2.98)\end{array}$ & $\begin{array}{l}-1.67 \\
(2.96)\end{array}$ & $\begin{array}{l}-2.85 \\
(2.44)\end{array}$ & $\begin{array}{l}-1.71 \\
(2.39)\end{array}$ & $\begin{array}{c}-4.32 \\
(2.80)\end{array}$ & $\begin{array}{l}-1.90 \\
(2.72)\end{array}$ & $\begin{array}{l}-4.34 \\
(2.15)\end{array}$ \\
\hline $\begin{array}{l}b_{3} \\
D D I V Y_{j} \\
S P 500_{j}\end{array}$ & $\begin{array}{c}0.74 \\
(2.76) \\
\end{array}$ & $\begin{array}{c}1.52 \\
(2.74)\end{array}$ & $\begin{array}{c}0.70 \\
(2.55)\end{array}$ & $\begin{array}{c}1.30 \\
(2.29)\end{array}$ & $\begin{array}{c}0.45 \\
(1.73) \\
\end{array}$ & $\begin{array}{c}1.43 \\
(2.55)\end{array}$ & $\begin{array}{c}1.05 \\
(2.17)\end{array}$ & $\begin{array}{c}1.09 \\
(1.38)\end{array}$ \\
\hline $\begin{array}{l}b_{4} \\
\text { IIZEN }_{j}\end{array}$ & $\begin{array}{c}-0.001 \\
(3.91)\end{array}$ & $\begin{array}{c}-0.003 \\
(3.81)\end{array}$ & $\begin{array}{c}-0.001 \\
(2.82)\end{array}$ & $\begin{array}{c}-0.002 \\
(1.89)\end{array}$ & $\begin{array}{c}-0.001 \\
(2.40)\end{array}$ & $\begin{array}{c}-0.002 \\
(3.12)\end{array}$ & $\begin{array}{c}-0.001 \\
(2.54)\end{array}$ & $\begin{array}{l}0.000 \\
(0.49)\end{array}$ \\
\hline $\begin{array}{l}b_{5} \\
L T Y L D_{j}\end{array}$ & $\begin{array}{c}0.12 \\
(3.22)\end{array}$ & $\begin{array}{c}0.28 \\
(3.79)\end{array}$ & $\begin{array}{c}0.13 \\
(3.51)\end{array}$ & $\begin{array}{c}0.31 \\
(3.98)\end{array}$ & $\begin{array}{c}0.12 \\
(4.72)\end{array}$ & $\begin{array}{c}0.17 \\
(1.82)\end{array}$ & $\begin{array}{c}0.13 \\
(4.21)\end{array}$ & $\begin{array}{c}0.18 \\
(2.09)\end{array}$ \\
\hline $\begin{array}{l}b_{6} \\
\text { Age }_{j}\end{array}$ & & & $\begin{array}{c}-0.0001 \\
(0.12)\end{array}$ & $\begin{array}{c}-0.0002 \\
(0.16)\end{array}$ & & & $\begin{array}{c}0.001 \\
(1.11)\end{array}$ & $\begin{array}{l}0.002 \\
(1.23)\end{array}$ \\
\hline $\begin{array}{l}b_{7} \\
L_{T V O L_{j}}\end{array}$ & & & $\begin{array}{l}0.003 \\
(1.50)\end{array}$ & $\begin{array}{l}0.008 \\
(2.06)\end{array}$ & & & $\begin{array}{l}0.004 \\
(1.46)\end{array}$ & $\begin{array}{l}0.008 \\
(1.41)\end{array}$ \\
\hline $\begin{array}{l}b_{8} \\
\text { ILLIQ }\end{array}$ & & & $\begin{array}{l}0.001 \\
(0.57)\end{array}$ & $\begin{array}{l}0.011 \\
(2.04)\end{array}$ & & & $\begin{array}{l}0.009 \\
(1.34)\end{array}$ & $\begin{array}{l}0.027 \\
(1.94)\end{array}$ \\
\hline $\begin{array}{l}b_{9} \\
R O A_{j}\end{array}$ & & & $\begin{array}{l}0.005 \\
(0.76)\end{array}$ & $\begin{array}{c}-0.017 \\
(1.27)\end{array}$ & & & $\begin{array}{l}0.003 \\
(0.55)\end{array}$ & $\begin{array}{c}-0.010 \\
(0.68)\end{array}$ \\
\hline $\begin{array}{l}b_{10} \\
R E P_{j} \\
\end{array}$ & & & $\begin{array}{l}0.009 \\
(0.73) \\
\end{array}$ & $\begin{array}{c}-0.019 \\
(0.76)\end{array}$ & & & $\begin{array}{l}0.013 \\
(0.69) \\
\end{array}$ & $\begin{array}{r}0.007 \\
(0.18) \\
\end{array}$ \\
\hline $\begin{array}{l}\text { Adjusted } \\
R^{2}\end{array}$ & $7.3 \%$ & $7.2 \%$ & $7.3 \%$ & $7.4 \%$ & $12.04 \%$ & $10.02 \%$ & $14.49 \%$ & $13.04 \%$ \\
\hline No. Obs & 4507 & 4507 & 4237 & 4237 & 4507 & 4507 & 4237 & 4237 \\
\hline
\end{tabular}

Regressions of $C A R_{j}$, the two-day abnormal return on days 0 (the dividend announcement day) and +1 , relative to the return on a portfolio of the size decile to which the stock belongs; and $C A R 13_{j}$, the cumulative abnormal return over days -11 to +1 . Estimation is by pooled time-series and cross-section models, (5-1) and (6-1), and by year-by-year regressions (Fama-Macbeth method), models (5-2) and (6-2). DDIVY $Y_{j}$ is the increase in dividend yield of firm $j, I N S T_{j}$ is institutional holding as a fraction of firm's $j$ outstanding shares at the end of the quarter before the dividend announcement is made, $S P 50 O_{j}$ is a dummy variable that equals 1 if firm $j$ is included in the $\mathrm{S} \& \mathrm{P} 500$ index, $L T Y L D_{j}$ is the firm's long-term yield in the year before the dividend announcement, $S I Z E N_{j}$ is the firm size deflated by the S\&P 500 index (the base is 1962), $A G E_{j}$ is the number of years between the first observation in CRSP and this dividend announcement date (in logarithm). $L T V O L_{j}$ is the standard deviation of monthly returns from month -24 to month -1. $I L L I Q_{j}$, the stock illiquidity, is the daily ratio of absolute return to total dollar volume averaged over days -252 to -2 . $R O A_{j}$ is the return on assets (EBITDA/total 
assets) and $R E P_{j}$ is stock repurchase (equity repurchase/market capitalization at the end of the fiscal year), both for the year before the dividend increase announcement. The pooled model includes quarterly dummy variables and 57 industry dummy variables corresponding to 57 two-digit SIC industries. In the Fama-Macbeth annual regressions, there are 13 industry dummy variables (aggregation of groups of two-digit industries). In the pooled regressions, the $t$-statistics are calculated using White's (1980) robust standard errors. In the Fama-Macbeth regressions, the model is estimated across stocks for each year $y, y=1980, \ldots 1998$. The table presents the weighted means of the 19 annual coefficients, the weights being the squared coefficient standard errors. The $t$ statistics are calculated accordingly. The critical $t$ values are 2.10 for $5 \%$ two-tail test and 1.73 for 5\% one-tail test. Estimation period: 1980-1998. 
Table 4

Changes in $E \Delta I N S T_{j}$, the excess change in institutional holdings around dividend increase announcements

\begin{tabular}{|l|c|c|c|c|c|c|}
\hline Quarter & Mean & $\begin{array}{c}t \text {-statistic: } \\
\text { difference } \\
\text { from } \\
\mathrm{q}=+1\end{array}$ & $\begin{array}{c}I N S T_{j}^{0}- \\
\text { weighted } \\
\text { mean }\end{array}$ & $\begin{array}{c}\text { Proportion } \\
\text { positive }\end{array}$ & $\begin{array}{c}\text { Quarterly } \\
\text { mean }\end{array}$ & $\begin{array}{c}I N S T_{j}^{0}- \\
\text { weighted } \\
\text { quarterly } \\
\text { mean }\end{array}$ \\
\hline & $(\mathrm{a})$ & $(\mathrm{b})$ & $(\mathrm{c})$ & $(\mathrm{d})$ & $(\mathrm{e})$ & $(\mathrm{f})$ \\
\hline $\mathrm{q}=-2$ & 0.00166 & 2.37 & 0.00305 & 0.514 & 0.00145 & 0.00217 \\
& $(3.78)$ & & $(4.55)$ & $(1.92)$ & $(1.50)$ & $(2.08)$ \\
\hline $\mathrm{q}=-1$ & 0.00246 & 3.55 & 0.00298 & 0.533 & 0.00271 & 0.00341 \\
& $(5.45)$ & & $(6.29)$ & $(4.52)$ & $(2.32)$ & $(2.81)$ \\
\hline $\mathrm{q}=0$ & 0.00138 & 1.95 & 0.00044 & 0.520 & 0.00149 & 0.00059 \\
& $(3.16)$ & & $(0.98)$ & $(2.70)$ & $(1.27)$ & $(0.48)$ \\
\hline $\mathrm{q}=+1$ & 0.00012 & & -0.00099 & 0.508 & 0.00010 & -0.00088 \\
& $(0.25)$ & & $(2.04)$ & $(1.29)$ & $(0.09)$ & $(0.76)$ \\
\hline
\end{tabular}

$E \Delta I N S T_{j}=\Delta I N S T_{j}-\triangle I N S T m . \Delta I N S T_{j}$ is the quarterly change in $I N S T_{j}$ and $\triangle I N S T m$ is the quarterly change in $I N S T$ for all firms. The figures are $\log \left(1+E \Delta I N S T_{j}\right)$.

The quarterly mean is the average over the quarters of each quarter's average $E \Delta I N S T_{j}$. Quarter 0 is the quarter during which the dividend announcement is made. $I N S T_{j}^{0}$ is measured after the dividend announcement.

$t$-statistics are in parentheses. In column (d), the $t$-statistic is of a test that the proportion is different from 0.50 . 
Table 5

The determinants of the likelihood of dividend changes

\begin{tabular}{|l|c|c|}
\hline Parameter & $\begin{array}{l}\text { Pooled } \\
\text { regression }\end{array}$ & $\begin{array}{l}\text { Fama- } \\
\text { Macbeth }\end{array}$ \\
\hline$\theta_{1}$ & -0.15 & -0.23 \\
$I N S T_{j}$ & $(3.01)$ & $(4.22)$ \\
\hline$\theta_{2}$ & -0.03 & -0.05 \\
$S P 500_{j}$ & $(1.60)$ & $(2.53)$ \\
\hline$\theta_{3}$ & -10.56 & -9.18 \\
$L T Y L D_{j}$ & $(19.15)$ & $(7.96)$ \\
\hline$\theta_{4}$ & -31.22 & -32.06 \\
$D_{F} I F L D_{j}$ & $(48.28)$ & $(21.65)$ \\
\hline$\theta_{5}$ & 0.07 & 0.07 \\
$S I Z E N_{j}$ & $(8.52)$ & $(9.34)$ \\
\hline$\theta_{6}$ & 0.13 & 0.12 \\
$P R C_{j}$ & $(7.23)$ & $(5.87)$ \\
\hline$\theta_{7}$ & -0.19 & -0.23 \\
LTVOL $_{j}$ & $(6.62)$ & $(5.75)$ \\
\hline
\end{tabular}

Estimations of the pooled model (7-1) and the year-by-year model (7-2) (Fama-Macbeth method). The dependent variable equals $+1,0$ or -1 if the dividend announcement for company $j$ is, respectively, an increase, no change or decrease in dividend compared to the dividend in the previous quarter. For variable definitions and model specification, see Table 3. DIFYLD $D_{j}$ is the difference between the dividend yield of the last quarter before the dividend announcement and the long-term yield, and $P R C_{j}$ is the stock price (in logarithm) at the end of the quarter before the dividend announcement. 
Table 6

The effect of dividend surprise and institutional holdings on stocks' CAR

Panel a: Models (8-1) and (8-2)

\begin{tabular}{|l|c|c|c|c|}
\hline & \multicolumn{2}{|c|}{ Pooled regression } & \multicolumn{2}{c|}{ Fama-Macbeth } \\
\cline { 2 - 5 } & $C A R$ & CAR13 & CAR & CAR13 \\
\hline$\gamma_{1}$ & 0.012 & 0.008 & 0.006 & 0.004 \\
DIVSURP $_{j}$ & $(5.50)$ & $(1.73)$ & $(2.10)$ & $(1.32)$ \\
\hline$\gamma_{2}$ & -0.010 & -0.024 & -0.010 & -0.023 \\
$I N S T_{j}$ & $(3.31)$ & $(3.75)$ & $(3.15)$ & $(4.27)$ \\
\hline$\gamma_{3}$ & 0.002 & 0.006 & 0.002 & 0.006 \\
${\text { SP } 500_{j}}$ & $(1.53)$ & $(2.33)$ & $(1.49)$ & $(2.17)$ \\
\hline$\gamma_{4}$ & -0.0003 & -0.0023 & -0.001 & -0.002 \\
SIZEN $_{j}$ & $(0.60)$ & $(2.22)$ & $(0.95)$ & $(2.64)$ \\
\hline$\gamma_{5}$ & 0.124 & 0.345 & 0.164 & 0.276 \\
LTYLD $_{j}$ & $(3.44)$ & $(4.61)$ & $(5.76)$ & $(3.39)$ \\
\hline Adj. $R^{2}$ & $6.59 \%$ & $6.45 \%$ & $10.07 \%$ & $8.40 \%$ \\
\hline
\end{tabular}

Panel B: Models (9-1) and (9-2)

\begin{tabular}{|c|c|c|c|c|}
\hline & \multicolumn{2}{|c|}{ Pooled regression } & \multicolumn{2}{|c|}{ Fama-Macbeth } \\
\hline & $C A R$ & CAR13 & $C A R$ & CAR13 \\
\hline $\begin{array}{l}\gamma_{1} \\
\text { DIVSURP }_{j}\end{array}$ & $\begin{array}{l}0.012 \\
(5.74) \\
\end{array}$ & $\begin{array}{l}0.009 \\
(2.03) \\
\end{array}$ & $\begin{array}{l}0.006 \\
(2.22) \\
\end{array}$ & $\begin{array}{l}0.006 \\
(1.69) \\
\end{array}$ \\
\hline $\begin{array}{l}\gamma_{2} \\
\text { DIVSURP }_{j} * I N S T_{j}\end{array}$ & $\begin{array}{l}-0.002 \\
(3.53)\end{array}$ & $\begin{array}{l}-0.005 \\
(3.91)\end{array}$ & $\begin{array}{l}-0.002 \\
(3.31)\end{array}$ & $\begin{array}{l}-0.005 \\
(4.39)\end{array}$ \\
\hline $\begin{array}{l}\gamma_{3} \\
\text { DIVSURP }\end{array} *$ SP $500^{2}$ & $\begin{array}{l}0.000 \\
(1.35)\end{array}$ & $\begin{array}{l}0.001 \\
(2.12)\end{array}$ & $\begin{array}{l}0.000 \\
(1.27)\end{array}$ & $\begin{array}{l}0.001 \\
(2.06)\end{array}$ \\
\hline $\begin{array}{l} \\
\gamma_{4} \\
\text { SIZEN }_{j}\end{array}$ & $\begin{array}{l}-0.0002 \\
(0.44)\end{array}$ & $\begin{array}{l}-0.0021 \\
(2.08)\end{array}$ & $\begin{array}{l}-0.001 \\
(0.81)\end{array}$ & $\begin{array}{l}-0.002 \\
(2.45)\end{array}$ \\
\hline $\begin{array}{l}\gamma_{5} \\
L T Y L D_{j}\end{array}$ & $\begin{array}{l}0.125 \\
(3.46)\end{array}$ & $\begin{array}{l}0.347 \\
(4.64)\end{array}$ & $\begin{array}{l}0.163 \\
(5.74)\end{array}$ & $\begin{array}{l}0.275 \\
(3.36)\end{array}$ \\
\hline Adjusted $R^{2}$ & $6.61 \%$ & $6.46 \%$ & $10.09 \%$ & $8.43 \%$ \\
\hline
\end{tabular}

Regressions of $C A R_{j}$ and $C A R 13_{j}$. Estimation is by a pooled time-series and cross-section model, (8-1) and (9-1), and year-by-year (Fama-Macbeth) model (8-2) and (9-2). For variable definitions and model specification, see Table 3. DIVSURP $P_{j}$ (the dividend surprise) is obtained from the ordered probit model (7) as the expectation of the structural residual conditional on the event. 
Figure 1

The pattern of $C A R_{y}$ over time for dividend increases and decreases.
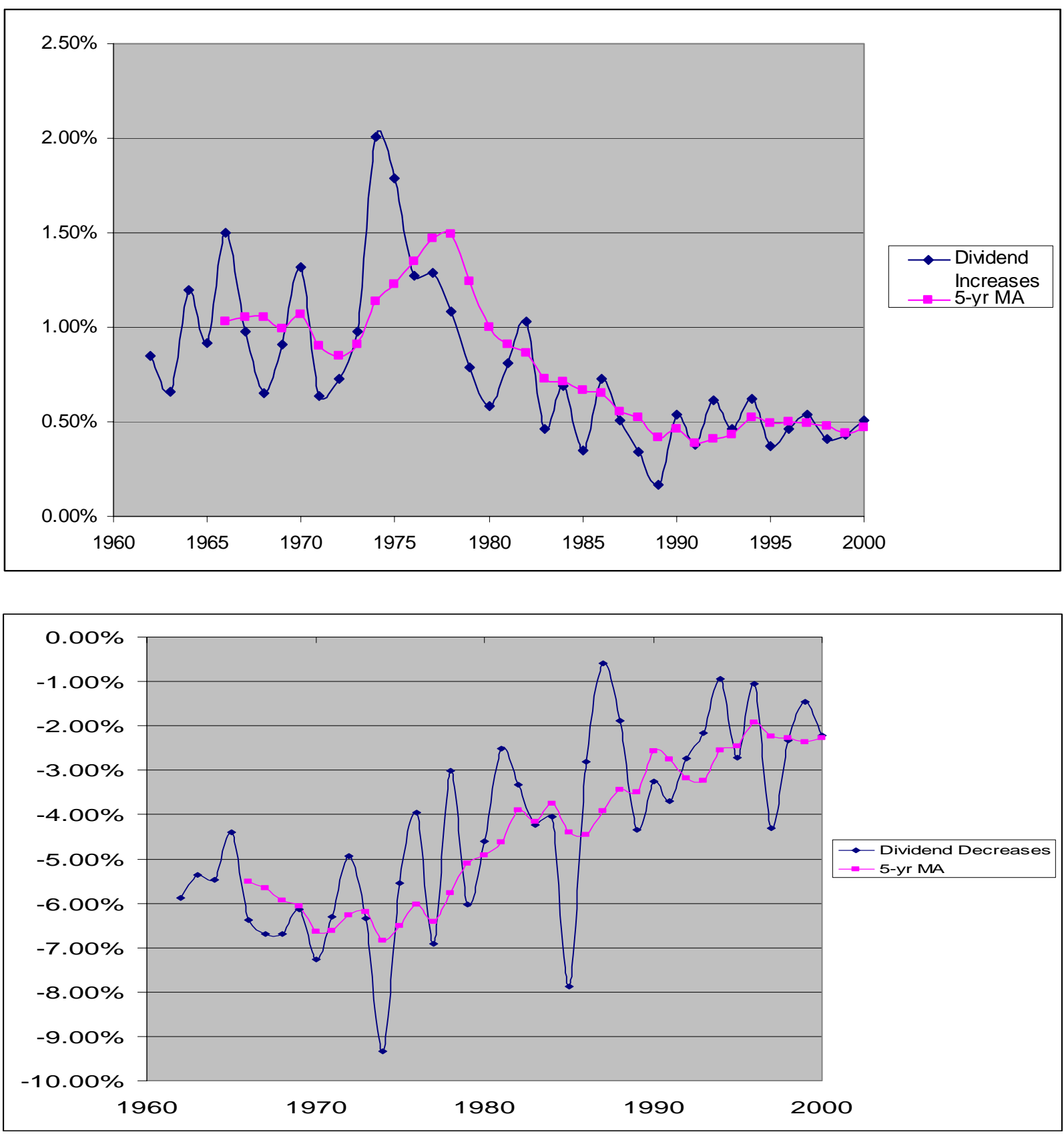

$C A R_{y}$ is the yearly average of two-day cumulative abnormal return, days 0 and +1 (day 0 is the dividend announcement day). There are two figures, one for dividend increases and one for dividend decreases.

The solid line depicts $C A R_{y}$ for the year. The dashed line is the five-year moving average. 
Figure 2

The pattern of the dividend response coefficient over time for dividend increases

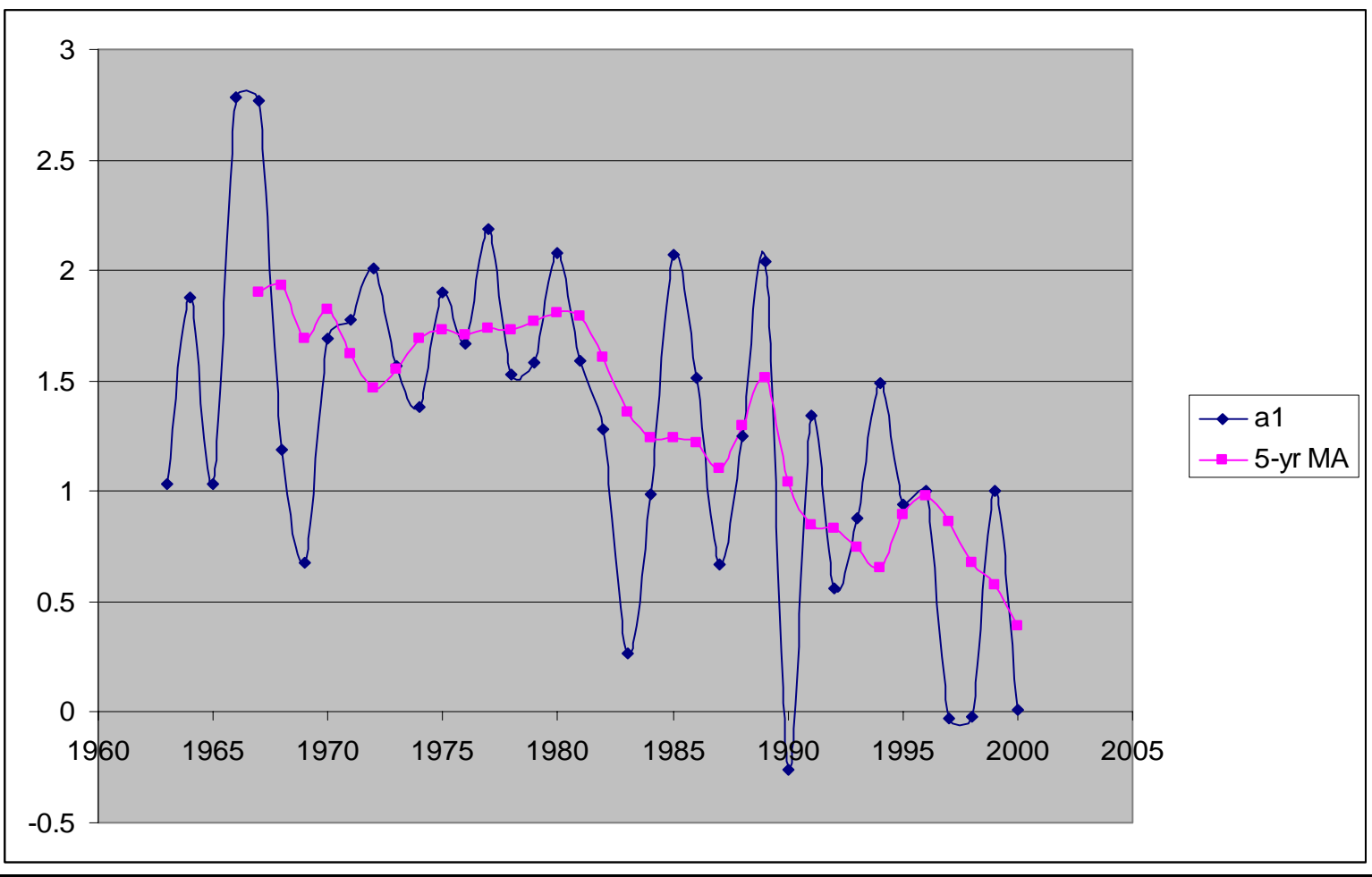

The figure plots the dividend response coefficient, $\alpha_{1}$, from the regression model (3) $\quad C A R_{j}=\alpha_{0}+\alpha_{1} D D I V Y_{j}+\alpha_{2} \operatorname{SIZEN}_{j}+\alpha_{3} L T Y L D_{j}+e_{j}$.

The model is estimated for each year across all dividend increase announcements during the year. $C A R_{j}$ is the two-day cumulative abnormal return, days 0 and +1 (day 0 is the dividend announcement day). $D D I V Y_{j}$ is the change in the dividend yield compared to the dividend yield in the quarter before the change. $S I Z E N_{j}$ is the stock capitalization normalized by the S\&P 500 index. $L T Y L D_{j}$ is the stock's long-term yield, in the year before the dividend announcement.

The solid line depicts the estimated $\alpha_{l}$ for the year. The dashed line is the five-year moving average. 
Figure 3

Institutional holdings and cumulative abnormal returns (CARs), day -11 to day +1

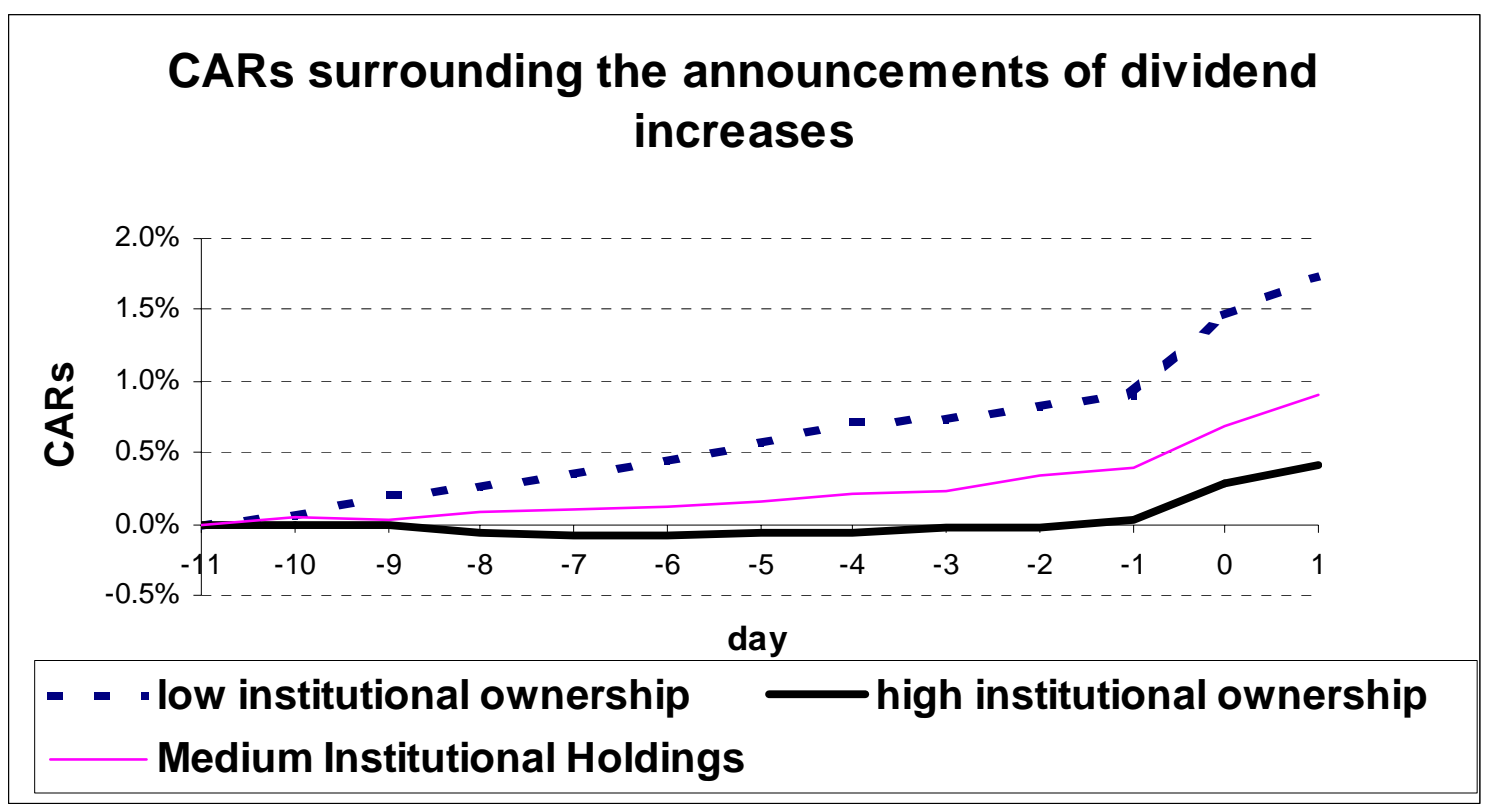

The CARs are averaged for three portfolios: high, medium and low institutional holdings. Stocks for which there is a dividend increase announcement in a quarter are allocated into one of the three portfolios according to the institutional holding of the stock. 